
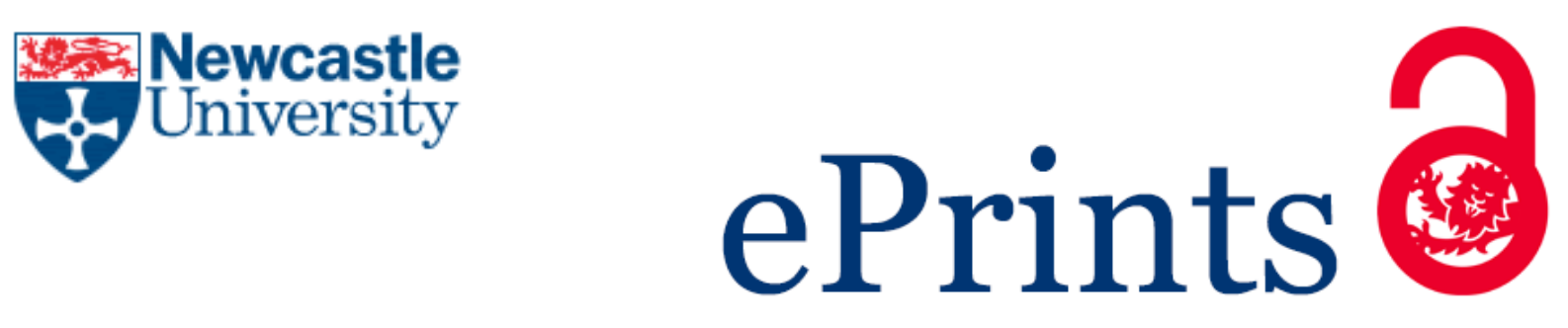

Clark A.

Public Administration and the Integrity of the

Electoral Process in British Elections.

Public Administration 2015, 93(1), 86-102.

\title{
Copyright:
}

This is the accepted version of the above article which has been published in final form at:

http://dx.doi.org/10.1111/padm.12106

Date deposited:

$27 / 03 / 2014$

Embargo release date:

31 July 2016

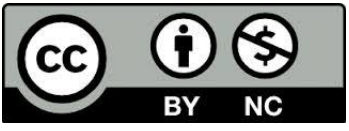

This work is licensed under a Creative Commons Attribution-NonCommercial 3.0 Unported License 
Public Administration and the Integrity of the Electoral Process in British Elections

\author{
Dr. Alistair Clark, \\ Politics, \\ Newcastle University, \\ Newcastle upon Tyne, \\ NE1 7RU. \\ E: alistair.clark@ncl.ac.uk \\ T: 01912087922
}

This is the accepted version of the following article:

Clark, A. 'Public Administration and the Integrity of the Electoral Process in British Elections', Public Administration, which will be published in final form at: http://onlinelibrary.wiley.com/journal/10.1111/(ISSN)1467-9299 


\section{Public Administration and the Integrity of the Electoral Process in British Elections}

\section{Abstract}

Although Britain has often been held up as being a model of electoral integrity, recent controversies have suggested that this perception may not be wholly justified. This article explores overall standards of electoral administration across Britain, utilising performance reporting data for Returning Officers in the 2010 general election to outline a comprehensive measure for the integrity of the administration of the electoral process. Discussion begins by outlining the question of electoral integrity and, most importantly, the issue of electoral administration. The second section considers recent British controversies, while also outlining steps taken to monitor the performance of electoral administrators. The third section introduces the performance standards and the index of electoral integrity developed from these, while the fourth section presents an analysis. The article concludes with discussion of the challenges facing electoral administrators, and highlights the utility of an index of electoral integrity in helping electoral professionals address these challenges. 


\section{Public Administration and the Integrity of the Electoral Process in British Elections ${ }^{1}$}

Assessing the effectiveness and performance of public administration has been a key concern in many countries. Nowhere is this more crucial to democracies than in the field of electoral administration. Poor performance and difficulties in electoral administration have the potential to undermine both the legitimacy of the electoral process, and, potentially, of the government elected. Examination of electoral administration and integrity is therefore of vital interest in democracies, yet as Wise (2001: 138) notes 'public administration has not devoted attention to electoral administration with anything like the priority it has given to other areas of public policy'.

This article provides an exploratory assessment of overall standards of electoral administration across Britain in the 2010 general election. Although often held up as being a model of electoral integrity, recent controversies in Britain have suggested that this perception may not be wholly justified. Incidents casting doubt on the integrity of the process have been evident across the whole of the UK. Many of these controversies about the integrity of the electoral process can be attributed to difficulties in electoral administration.

This is an understudied area of public administration in Britain. Britain has a decentralised system of electoral administration, with local council Returning Officers (ROs) responsible for the conduct of elections in their jurisdiction. Performance standards for ROs in the UK were set by the Electoral Administration Act (2006). Compliance with these standards now have to be reported to the UK Electoral Commission. The article utilises the subsequent performance reporting data for ROs in the 2010 general election to outline a comprehensive measure for the integrity of the administration of the electoral process in general elections in Britain. Discussion begins by assessing the question of electoral integrity 
as understood by comparative scholars and its component elements, most importantly, the issue of electoral administration. The second section considers recent British controversies which have put the administration of elections under unprecedented scrutiny, while also outlining steps taken to monitor the performance of electoral administrators. The third section introduces the data deployed by outlining the performance standards for ROs, while the fourth section presents an analysis of the data. The article concludes with discussion of the challenges facing electoral administrators and the potential consequences of these challenges in maintaining electoral integrity in Britain.

\section{Integrity, Administration and the Electoral Process}

Interest in the conduct of elections has concerned itself primarily with questions of campaigning, voting behaviour and electoral systems. The question of electoral integrity is only beginning to be seriously considered in this research (Norris, 2013a). The democratic transitions literature has taken electoral integrity most seriously. In that field, process has been seen as important as outcomes in determining the legitimacy of elections in what are often highly conflictual political situations (Elklit and Reynolds, 2005; Mozaffar and Schedler, 2002; Pastor, 1999). In advanced democracies, the integrity of the electoral process is essentially taken for granted for a variety of reasons. Public administration in developed countries has often lengthy experience of conducting elections. Consequently questions about the integrity of the process tend only to be raised when something goes badly wrong. For example, the disputed 2000 presidential election in the USA stimulated assorted research on American electoral integrity and administration (Alvarez and Hall, 2006; Montjoy, 2008; Wise, 2001). ${ }^{2}$ 
Electoral integrity can be thought of in broad and narrow terms. At its broadest, this is placed within a framework of promoting democracy, respect for fundamental freedoms and human rights. Such freedoms are fundamental to declaring any election 'free and fair' (Elklit and Svensson, 1997). The Organisation for Security and Co-operation in Europe (OSCE) (2010a: 18 and Appendix A) sets out a range of requirements relating to elections. These include: holding free elections at regular intervals; guaranteeing universal and equal suffrage; respecting the right of citizens and parties to compete for office; the absence of violence or intimidation; non-discriminatory media access; ensuring votes are cast by secret ballot and results reported honestly and openly; and ensuring candidates receiving the necessary support are permitted to hold office until their term expires. Norris (2013b) shows how such international standards have gained broad acceptance across the world, while a grouping of Electoral Assistance Bodies, the ACE Electoral Knowledge Network, summarise the five key elements of electoral integrity as being:

- A set of standards based on generally accepted democratic principles;

- A legal framework that imposes checks and balances on the institutional structure;

- Firmly entrenched protection mechanisms, such as independent observation;

- Enforcement measures;

- Fair, transparent and equitable election administration (ACE Project, n.d.)

Electoral integrity can be cast much more narrowly around this latter point of fair, transparent and equitable electoral administration. Minnite (2010) suggests that while the conduct of candidates, parties and political organisations can do much to raise doubts about the integrity and fairness of the electoral process, what gives them an opportunity to raise questions often comes down to, in the first place, standards of administration in conducting 
elections. Elklit and Svensson (1997) observe that a necessary feature in determining the fairness of elections is to assess how rules and laws are applied in practice. For Schaffer (2008: 3-4) vote integrity simply means an honest and accurate tallying of the vote. A similar definition is used by the UK Electoral Commission (2009a). For it, electoral integrity is about a secure process for registration and voting. This means that voters should know that: information about them is accurate; be clear about the use of such information; expect that their vote is confidential and free from pressure; and that their vote is counted. Equally, candidates and parties should be able to expect transparent processes and accurate election results.

Much of the relatively limited literature on electoral administration focuses on whether countries have independent Electoral Management Boards (EMBs) or Electoral Commissions (Elklit and Reynolds, 2001; Maley, 2001, Pastor, 1999). This is far from the whole story. As Mozaffar and Schedler (2002: 8-9) observe, running a credible election is a balancing exercise between three conflicting demands: administrative efficiency; political neutrality; and public accountability. They argue that it is administrative efficiency which is most vulnerable to mistakes and errors which can negatively impact upon perceptions of the whole electoral process. They highlight the sheer scale of organisation and logistics needed to run a national election process to almost inevitably short timescales, with the vast majority of staff being non-specialists trained and employed only for the very short term conduct of the election. While this might appear to require central co-ordination and planning of resources, in reality casting a vote is something that, of necessity, happens in the voter's local area. This means that running elections also depends to a large extent on how they are implemented locally. However, localised standards in the implementation of electoral administration can vary considerably, rendering perceptions of the electoral process as, at best, not uniform, and at worst, threatening the credibility or integrity of the process (Atkeson and Saunders, 2007; 
Hale and Slaton, 2008; Hall et al., 2007; Highton, 2006). To Birch (2011: 26), errors and difficulties in this complex administrative process represent 'mispractice', while to Vickery and Shein (2012) they represent 'malpractice', resulting from the failure of electoral professionals to execute their duties effectively.

Electoral administration tends only to attract critical attention when errors or problems compound to highlight and raise questions about the integrity of the process. Elklit and Reynolds (2005: 148) suggest this matters less, indeed credibility survives, if the errors are random and do not impact upon the outcome. However, given the fragility of democratic practices in many states, and the high levels of scepticism and distrust about politics and the electoral process in advanced democracies, such errors or problems are not to be taken lightly since they can contribute further to perceptions that the political process is inherently flawed and unreliable. Consequently, Pastor (1999: 15) ultimately suggests that electoral administration should be considered an independent variable in judging whether elections are seen as successful or flawed.

Effective administration is crucial at all stages of the electoral process. Pre-election tasks are manifold but include completing an up-to-date electoral register, finding and organising suitable polling stations, training election workers, public education campaigns for voters and candidates, registering parties and candidates and ensuring adequate supplies of ballot papers. During the election, the challenge is to ensure that electors can cast their vote and that that vote is then counted properly, or at least transported to a counting centre where it can be appropriately recorded, and that the results are verified and transparent. Postelection, the cycle begins again, with any challenges to results requiring appropriate adjudication and with the view to learning lessons and to reforming the process if necessary.

A number of checklists have been proposed to allow an overall assessment of the state of electoral administration within a country. Elklit and Reynolds (2001) highlight twelve 
steps in the electoral process and subdivide these steps into 47 different variables. For instance, in relation to ballot access, the steps include how parties and candidates are registered, what rules there are for independent candidates, the mechanisms for ballot paper access, and ballot paper design. In a later article (Elklit and Reynolds, 2005), they extend this framework further to 54 variables, dividing their various steps into essential, important and desirable characteristics all of which are given weightings according to their importance in their schema. Pastor (1999) divides his checklist into pre-election, election and post-election phases with 22 indicators in total for application to developing countries. Mozaffar and Schedler (2002) distinguish between a threefold approach of rule-making (i.e. the rules of electoral competition and governance), rule application (i.e. organising the election process) and rule adjudication (certifying results and resolving disputes). Implicit in most of these approaches is the idea that the administrative aspects of electoral integrity can be combined to provide an overall assessment of a set of elections (Elklit and Reynolds, 2005: 156; Gerken, 2012). This idea is returned to below.

\section{Electoral Integrity and British Politics}

For a long time, Britain was content to hold itself up as a model of how the electoral process should work to the rest of the world. As Stewart (2006: 667 and 654) observes 'both academics and politicians have taken the integrity of the electoral process for granted' and that 'it had been assumed, almost without question, that elections have been free from abuse'. Similarly, Watson (2011: 126) notes that international observers, allowed to observe a UK general election for the first time in 2010 , found 'striking ... the culture and tradition of trust and honesty that underpins our elections process'. Under the 1997-2010 Labour governments numerous 'electoral modernisation' measures meant that the electoral process in the UK 
came under increasing pressure. James (2010: 187; Wilks-Heeg, 2009) lists a number of acts of parliament between 1997 and 2006 which had considerable implications for the electoral process. These included the Representation of the People Act 2000, which permitted universal postal voting on demand, the Political Parties, Elections and Referendums Act 2000 which set up the Electoral Commission, and the European, Parliamentary and Local Elections (Pilots) Act 2004 which extended pilot schemes to European parliament elections. The stated intention behind many of these reforms had been to increase electoral participation. James (2010) suggests that this was less motivated by altruistic motives than by narrow party interest on the part of the post-1997 Labour governments.

Against this backdrop, a number of problems with the electoral process emerged from 2000 onwards. Some examples underline the point. Firstly, widespread postal vote fraud was uncovered in the Aston and Bordesley Green wards in Birmingham in the 2004 local elections. These were all-out elections, with Labour under pressure in inner city wards and in danger of losing its status as largest party on the city council. The contest saw record numbers of postal votes cast. There was extensive evidence of fraud, with a specially convened Election Court finding that the results in Aston and Bordesley Green had seen between 1,000-2,000 fraudulent postal votes cast in each ward, that these had affected the result and that these had been cast as part of a Birmingham-wide campaign by the Labour Party to counter its loss of support over the Iraq war (Stewart, 2006: 660-661). ${ }^{3}$ Secondly, the 2007 Scottish parliament elections experienced unprecedentedly high numbers of rejected ballots. From less than ten thousand (0.39\%) rejected ballot papers in the constituency element of the MMP electoral system in 1999 , this rose to 85,644 or $4.08 \%$ of all constituency votes cast. Similarly, levels of rejected regional list votes increased from just over $7,000(0.31 \%)$ in 1999 to 60,455 or $2.88 \%$ in 2007 . This led to a sharp rise in the number of seats where the number of rejected ballots was greater than the winning 
candidate's majority, from 2 of the 73 constituency seats in 1999 to 16 out of 73 in 2007 . With only a one seat difference determining the winner between the two major parties, Labour and the SNP, this had considerable potential to undermine the legitimacy of the whole election. ${ }^{4}$ Indeed, $88 \%$ of respondents to the 2007 Scottish election study thought that rejected ballots had been a very serious problem, while $62 \%$ thought it likely that the rejected ballots had affected the outcome (Denver et al., 2009).

Thirdly, after the close of polling in the 2010 general election, news began to break about some polling stations experiencing large queues of voters in the evening with some polling station administrators closing the doors at the requisite time of 10pm. Some voters, despite having turned out to vote in advance of the close of poll, were prevented from doing so. Elsewhere there was variation in practice, with other voters allowed into the polling station. Post-election investigations highlighted 27 polling stations in 16 constituencies in cities such as Birmingham, Newcastle, Manchester, Liverpool, Sheffield and Hackney where such incidents had happened and estimated that around 1,200 voters had been affected (Watson, 2011). ${ }^{5}$ Fourth, difficulties with the electoral process have not been confined solely to mainland Britain. The concurrent 2011 elections to the Northern Ireland Assembly and for Northern Irish councils, held at the same time as the 2011 referendum on changing the Westminster electoral system, were heavily criticised for the time it took to verify votes and to begin to get results for the various contests. Finally, local elections have seemed perhaps most problematical. In addition to the Birmingham case above, the 2000 elections for the Greater London Authority and Mayoral contest were plagued by high numbers of rejected ballots, while between 2000-2007 around 42 successful convictions for electoral fraud were brought against members of all three major parties as well as some minor parties in all police force areas in England (Wilks-Heeg, 2009: 104-106). 
Hyperbole is never far away with incidents of this sort. The Birmingham electoral court judge likened the postal voting fraud to something that might have happened in a Banana Republic, while The Scotsman (5 ${ }^{\text {th }}$ May 2007) proclaimed the 2007 Scottish elections 'the worst poll debacle in the history of British democracy' (Denver et al., 2009: 19; Mawrey, 2005: 135). What they all have in common is that failings in electoral administration contributed considerably to these events. The decentralised nature of most British electoral administration is regularly noted as a difficulty, with the Electoral Commission currently having no power of direction over local council returning officers. Problems with effective planning, staffing and lack of funding for elections are regularly cited with Wilks-Heeg (2009: 106) referring to electoral administration as the 'Cinderella service' in councils, and these services being claimed often to be 'close to breaking point'. Unrealistic planning expectations and staffing are both identified as issues in the GLA elections in 2000, the 2010 election queues and the difficulties with vote verification in Northern Ireland in 2011 (Electoral Commission, 2011a; Watson, 2011: 131-132; Wilks-Heeg, 2009: 106). Other issues also impacted in 2010, such as inappropriate polling stations, inadequate supplies of ballot papers to meet turnout and the wrong ballot papers and registers delivered to polling stations (Watson, 2011: 132).

Difficulties also originate from national imperatives. Although there were some localised issues in the 2007 Scottish elections that contributed to ballot papers being rejected, the main reason was a change in ballot paper design aimed at not having regional list candidates seen as inferior to their constituency counterparts (Denver et al., 2009). Similarly, although the Electoral Commission and electoral administrators had warned against the potential for postal vote fraud in 2004 , the government chose to ignore such warnings (Stewart, 2006). The Birmingham electoral court judge was scathing, accusing the government 'not simply of complacency but denial' (Mawrey, 2005: 135). As he noted, 'the 
systems for dealing with fraud are not working well. They are not working badly. The fact is that there are no systems to deal realistically with fraud and there never have been' (Mawrey, 2005: 136, emphasis in the original). An editorial in The Independent (2012) suggested that this remained problematic seven years later, arguing that 'our democratic process needs better safeguards'. The investigation into the 2007 Scottish elections debacle was equally pointed, noting that 'almost without exception, the voter was treated as an afterthought by virtually all the other stakeholders' (Electoral Commission, 2007b: 120).

Analysts should be wary about attempts to generalise from a small number of examples. Nonetheless, Wilks-Heeg (2009: 106) suggests that problems are widespread in Britain's localised system of electoral administration. Consequently, some method of assessment is required which provides a broader sense of the picture nationally. It is to this that the next section now turns.

\section{Data and Methods}

The Electoral Commission was given responsibility for monitoring the performance of Returning Officers and other relevant electoral officers in the Electoral Administration Act (EAA) 2006. This gave the Commission the power to determine and publish performance standards for electoral registration officers, returning officers and regional counting officers, direct these officers to provide reports on their performance, and to publish its own assessment of the performance of electoral officers against these standards (Electoral Commission, 2009a). Returning Officers (ROs) are non-partisan civil servants responsible for the conduct and administration of elections. These standards have been used to report on their performance in the 2009 European and 2010 general elections (Electoral Commission, 2009b; 
2010b). Performance standards in both elections revolved around three broad areas from which seven measurable standards were derived. These are outlined in Table 1.

(Table 1 about here)

Established frameworks of judging election quality tend to utilise ordinal scales on which particular aspects of the election can be rated. In the most comprehensive academic version, Elklit and Reynolds (2005) offer observers a four point likert scale (3 very good; 2 good; 1 not satisfactory; 0 very poor) on which to rank 54 variables. They argue that such a methodology has a long record in judging issues like comparative democracy and corruption. A similar approach is taken by the Electoral Commission. They adopt a three point ordinal scale of: not currently meeting the performance standard; meeting the standard; and above the standard.

In each of these performance standards, a range of criteria are specified that the RO must meet to be classified under these response options. For example, under performance standard 3 relating to training, to be classified as not meeting the standard ROs would either not provide training or do so only at a basic level for permanent members of electoral staff. To be classified as meeting the standard, ROs must provide ongoing training to permanent and temporary staff about legislative requirements, ensure this includes information on access issues for polling station and count staff, and that these training activities are evaluated. To be above the standard, the RO must have a written plan for both permanent and temporary staff and that evaluation of this and training needs more broadly is carried out regularly. Similarly, under performance standard 5 on public awareness activity, to fail to meet the standard ROs would only provide minimal statutory information with no response mechanisms in place for voters. To meet the standard, the RO would have a formal written public awareness strategy, 
response mechanisms for interested voters, and communication with other relevant council departments. To be above the standard, the RO has worked with external bodies (e.g. local media, community groups and other interested electoral officers) to develop their communication strategy, and have an evaluation methodology to establish its effectiveness (Electoral Commission, 2009a). ${ }^{6}$ The benefit of such an approach is that, through these performance standards, the Electoral Commission can highlight specific areas where ROs need to improve and work with them to do so (Heinrich, 2002; James 2013).

There are two main difficulties. Firstly, by contrast with Elklit and Reynolds' (2005) comprehensive framework which is to be completed by expert observers, these performance standards are self-completed by ROs. Performance standards have been claimed to be open to manipulation as public administrators attempt to 'game' outcomes, to misdirecting administrators' activity towards targeted goals instead of other crucial, and unmeasured, ones and to being constrained in their achievement by external circumstances (Andrews et al., 2005; Heckman et al., 1997; Heinrich, 2002). The OSCE suggested this was problematic in their report on the 2010 elections (OSCE/ODIHR, 2010b: 8). Nevertheless, RO responses to these standards are audited, albeit on a sampled basis, and evaluated by the Electoral Commission. This has led to some self-assessments being regraded from the original assessment given by the RO (Electoral Commission, 2010b). This audit process means that the published results can be considered relatively reliable assessments of the standard of electoral administration within councils. ${ }^{7}$

Secondly, a key difficulty with assessments of the electoral process according to Elklit and Reynolds (2005: 149) is that there is seldom any variation in them. Elections tend to be judged either good or bad. This is a potential problem with the Electoral Commission's performance standards data; a three-point ordinal scale has little room for variation on the 
seven indicators used as performance standards in 2009-10. As Game (2006: 467) observes of another performance standards framework for local government:

The problem with a system that has to justify itself by producing regular evidence of continuous improvement is that sooner or later - in this case sooner - almost everyone arrives at or near the top of the scale, with apparently nowhere else to go. When the great majority become good or excellent, the terms lose any meaning they may have had and almost no-one is left in need of improvement.

As will be seen, this is a difficulty for the performance standards criteria for ROs. Moreover, a focus on these seven individual indicators by themselves means that assessments do not focus on the general picture, but instead more narrowly on the specifics of certain standards. Of course, this is what they were designed to do. Yet as Elkit and Reynolds (2005: 149) rightly observe, overall election quality can rarely be reduced to so few categories and instead reflects a continuum with multiple dimensions. They deal with this within their framework by creating an index of election quality derived from the sum of scores across their various indicators, and then standardising this index.

To provide such variation and an overall assessment, this article develops an index of election administration integrity derived from the Electoral Commission's RO performance standards data and inspired by the more comparative approaches discussed above (Elklit and Reynolds, 2005; Gerken, 2009). ${ }^{8}$ This is an additive index, created by summing the scores achieved on each of the seven performance standards set by the Electoral Commission, with values of 1 given to not currently meeting the standard, 2 given to meeting the standard, and 3 to where ROs were above the standard. The resulting integrity index therefore varies between a minimum score of 7 and a potential maximum score of $21 .^{9}$ The index is based on 
returns from 372 out of 379 local council returning officers in Britain who were responsible for running the 2010 general election in 632 constituencies. In other words, the analysis is undertaken at the level of these local authority returning officers, and based on a response rate of 98 per cent. ${ }^{10}$ Reliability analysis achieved a Cronbach's Alpha score of .765, thereby demonstrating that these indicators are suitable for index construction (Pennings et al., 1999: $96-97) .^{11}$

It should be noted that the Electoral Commission declined the opportunity to create such an overall performance index, claiming that this would 'maintain transparency and simplicity ... aggregating the total number of standards not met, met or exceeded across all seven standards may not give an accurate picture of performance' (Electoral Commission, 2009b: 8). ${ }^{12}$ Nevertheless, such an aggregate approach has been utilised in relation to performance standards data before in local government, notably the 2002-09 Comprehensive Performance Assessment (CPA) (Andrews et al., 2005: 641-643). Such an approach is therefore accepted in assessing public administration in Britain. The index offers a complementary and important advance on what is currently known about the performance of ROs in two key ways. It provides considerably more variation than permitted by the performance standards as originally reported. It also permits an overall view of electoral administration to be obtained, while enabling easier comparison of standards between different types of local government and areas within Britain than hitherto possible.

\section{Analysis}

RO performance standards were first reported on in a national election during the 2009 European parliament contest. The results, set out in the top half of table 2, essentially provided 'a positive picture of performance' in electoral administration across Britain 
(Electoral Commission 2009b: 25). Headline results showed that 96\% had met or exceeded standard 1 on the skills and knowledge of the returning officer while $90 \%$ of ROs had met or exceeded all three planning and organisation standards. However, achieving these standards was no guarantee of necessarily meeting the others; smaller proportions of around threequarters of ROs met or exceeded the standards on integrity, and participation. Two standards were of particular note. A total of 71 ROs (18.8\%) failed to meet the performance standard on maintaining the integrity of an election, while 69 ROs (18.3\%) failed to meet the performance standard on accessibility of information to electors. Thus around a fifth failed two of these key indicators, while almost 12 per cent also failed to meet the standard in planning and delivering public awareness activity. Even within the area of planning and organisation, which showed most compliance with the performance standards, 35 ROs did not meet one or more of the performance standards (Electoral Commission 2009b). While performance was therefore mostly satisfactory in that most ROs met or exceeded the standards, the numbers of ROs failing them were sufficient to cause concern since even small numbers of mistakes in electoral administration can lead to widespread scepticism about the credibility of the process.

(Table 2 about here)

A general election is of a different level of magnitude to low turnout 'second order' European elections. Watson (2011: 129) highlights the challenge faced by ROs in the 2010 general election by noting that nearly 24 million votes were cast in around 40,000 polling stations, with 5.8 million postal votes also being cast. Alongside this a further 13.6 million votes were cast in local elections in various parts of England. The lower half of table 2 presents ROs' performance in the 2010 general election. These results showed an 
improvement on all of the performance standards by comparison with the 2009 European elections. Very small proportions failed to meet each of the seven standards, with at most $8.1 \%$ not meeting the standard on accessibility of information to electors. These improvements were welcomed by the Electoral Commission, who had put considerable effort into helping ROs to comply with the standards in the aftermath of the 2009 European contests (Electoral Commission, 2010b).

This notwithstanding, three points are noteworthy. Firstly, despite these high standards being achieved, election night 2010 saw considerable controversy, as noted above, because queues built up outside a small number of polling stations with administrators' practice differing at each leading to some voters being turned away, and others not. Key factors leading to these difficulties included: over-allocation of voters to some polling stations; inadequate planning assumptions; higher than expected turnout in some locations; inappropriate premises; inadequate staffing levels; and a failure of monitoring and support on polling day (Electoral Commission, 2010a). There was no necessary link between failing a performance standard and such failings. In four areas where queues built up, ROs had failed to meet the skills and knowledge standard. In two of these areas the ROs had also failed to meet the training standard. In all the other areas, the ROs had either met or performed above the standard. Game's (2006) warning about what happens to performance standards when organisations are classified good or excellent, noted above, appears prescient here.

Secondly, the issues of integrity and accessibility of information to electors remained the most problematic. In a small number of councils the warnings about fraud from the Birmingham postal voting case, and about voters being an afterthought from the Scottish 2007 elections appear to not have been heeded. These failings appear persistent in some cases, with, for example, seven ROs below the standard in relation to standard 5 on public awareness in both 2009 and 2010. Thirdly, while these difficulties only take in a small 
number of councils, it still means that 21 ROs have failed the integrity standard, while 30 have not met the accessibility of information to voters standard. With an average of around 70,000 electors per constituency in 2010, and numerous councils administering multiple constituencies, there are potentially a large number of voters affected by such administrative failings.

(Figure 1 about here)

How do these performance standards look when combined into an overall picture? Figure 1 reports the distribution of the 2010 additive integrity index introduced above. This can vary from a score of 7 at the lower end, to a high of 21 at the top end of the index. In practice, the distribution is positively skewed with a skewness value of .489 . No RO failed to meet all performance standards and consequently the distribution ranges between 11 and 21, with 11 ROs being above the standard on all seven performance indicators and scoring the maximum 21. The index mean is 15.75 , with a standard deviation of 2.167 . This means that most ROs score somewhere between 13.6 and 17.9 on the index. The modal value, as evident in figure 1 , is 14 . In total, 38 ROs fall outside the standard deviation score at the bottom end of the index, while 82 ROs fall outside it at the top end of the index. In short, more than half of ROs (191 or $51.3 \%$ ) are located below the mean on the integrity index, while the remaining 180 or $48.7 \%$ perform above average. This provides a somewhat more nuanced, and national level, overview of local councils' performance standards in electoral administration than provided by viewing their responses one standard at a time.

(Table 3 about here) 
Table 3 lists the highest and lowest scoring councils across Britain in the 2010 general election. The most poorly performing councils - i.e. the thirteen authorities scoring least on the index - include some major urban areas responsible for multiple constituencies, such as Bristol and Newcastle upon Tyne, as well as the London boroughs of Barking and Dagenham, and Lambeth. The top performing councils are those eleven authorities that achieved a maximum score of 21 on the integrity index. They include some urban areas, notably Westminster, Lewisham, Reading and Rotherham, but also include some more rural authorities such as Cornwall, Perth and Kinross and Pembrokeshire. There was no significant difference in performance between those authorities that experienced election night queuing problems, who scored slightly less than the index mean at 15.64, and those who experienced no queues, who averaged 15.75 .

How might variation on the index be explained? Despite the numerous checklists described above, analysts have little empirical evidence to suggest what may drive higher levels of performance in election administration in advanced democracies like Britain. A number of potential explanations can begin to be explored however. The first set of explanations relate to the electoral structure of the local area where elections are being administered. Three issues can be identified as potentially impacting upon performance: having to administer a larger electorate; having concurrent multi-level elections; and administering multiple constituencies. Both concurrent elections and ROs administering multiple constituencies are common in Britain and may complicate the issue for administrators because they add to the pressure on them to deliver more than one set of results in a very limited timescale.

Electorate size appears to have little effect. Measured as electorate density (a ratio of the number of electors / council area in hectares), and correlated with performance on the integrity index, this returned a very weak Pearson correlation of .055 which was some 
distance $(.291)$ from statistical significance. ${ }^{13}$ Performance in the 163 councils which ran local elections concurrent with the general election show little effect; those that had no local elections scored on average slightly higher on the index at 15.85 than those also running local contests, which averaged 15.61. ${ }^{14}$ Analysis of variance (ANOVA) showed this was not statistically significant. By contrast, responsibility for multiple constituencies did seem to have an impact in 2010. ${ }^{15}$ Around 154 ROs ran multiple constituencies and they recorded a mean on 16.16 on the index, compared with a mean of 15.45 for those only running one constituency. For multiple constituencies, ANOVA returned a statistically significant relationship at the $\mathrm{p}<0.01$ level (.002), a between groups F-value of 9.858 , and an eta value for the strength of relationship of .161.

To what extent might performance be determined by type of local authority? There are two potential sets of expectations. Firstly, the Electoral Commission in both their 2009 and 2010 assessments found variation between different council types when reviewing RO performance one standard at a time. Thus, for example, in 2010 ROs from district councils were less likely than others to report meeting the standards on public awareness and accessibility of information to electors (standards 5 and 6) than those from London boroughs. District councils were also less likely to have met the standard for integrity (standard 4) by a magnitude of two-thirds. By contrast, unitary councils were most likely to have assessed themselves as being below the standard in relation to training (standard 1). Differential performance was also found between different types of local authority in 2009 (Electoral Commission, 2009b; 2010b). On the other hand, Murphy et al. (2011) tested for differences between different types of local authorities on a different performance assessment regime, that attempting to measure Comprehensive Performance Assessment (CPA) of English local government between 2002-2009. They found little difference between different types of authority, arguing that variation occurred as much between as within different types of local 
government structures. Similarly, Andrews et al. (2005) found that poor performance in CPA was significantly influenced by exogenous factors such as social structure. From these arguments it might be expected that there is little difference in performance in electoral integrity between different types of council.

(Table 4 about here)

Table 4 presents the mean index score in 2010 by council type in descending order. Scottish unitaries perform best with an average score of 16.68, while English two-tier districts appear to perform worst with a mean integrity score of 15.39. While strength of association is not strong, with an eta value of just .205, these results return a between groups ANOVA F-value of 2.657 which is statistically significant at the $p<0.05$ level (.016). This suggests that differences between council types may be systematic and more than just the result of chance. Indeed, taking the standard deviation into account, the main distribution of performance for the two groups of best performing councils - Scottish unitaries and London boroughs - is in a somewhat higher range than that for two-tier districts. ${ }^{16}$

The main reason for Scottish unitaries and London boroughs performing well appears to be one of co-operation and coordination. The Scottish regional returning officer set up an Interim Electoral Management Board in late 2008 to improve consistency of practice. This is now established on a statutory basis and provides a power of direction to ROs (Electoral Commission, 2009b: 19; Watson, 2011). This clearly had pay-offs in 2010, with Scottish ROs found to be making better use of planning and risk management tools than before (Electoral Commission, 2010b). London boroughs also regularly met in London-wide Chief Executive meetings where electoral issues were often discussed particularly in relation to planning, organisation and the skills of the returning officer in 2009. Although the 
constituency-based nature of the general election means that there was no regional structure in place for co-ordination in 2010, it can nevertheless be expected that such discussions have had a beneficial impact over the immediate to mid-term period in London, with London authorities also utilising training events run by the Association of Electoral Administrators to help coordination (Electoral Commission, 2009b; 2010b). Moreover, both Scotland and London had previously been found wanting in terms of electoral integrity; Scotland with the rejected ballots issue in 2007, and London authorities in the 2000 GLA elections. The power of public censure cannot therefore be discounted as a potential driver for subsequent improvement and higher achievement in either case. In addition, both London and Scotland now have devolved political structures which may serve to focus electoral administrators' minds in terms of accountability for failings.

(Table 5 about here)

An alternative way of assessing the territorial distribution of electoral integrity in the 2010 general election is to examine RO performance by region. This helps control for council type since most different council types are found in each region. Table 5 presents average RO performance by English region. Scotland, London and Wales are excluded from this table since their regional performance is the same as found in table 4 above. Analysed at this level suggests a variation in performance in electoral integrity across the English regions, at lower levels than that found in London, Scotland or Wales. Four regions perform at close to the same level, with the West and East Midlands, South West and South East all recording scores of between 15.67-15.87. Yorkshire and the Humber performs best with a mean score on the index of 16, while Eastern region performs worst with the lowest score integrity score in this analysis of 14.79. As with council types, measures of association are relatively weak with an 
eta value of .238. However, with a between groups ANOVA F-value of 2.155, these regional results are also statistically significant at the $\mathrm{p}<0.05(0.02)$ levels, again indicating that this is something more than just a chance pattern of performance. ${ }^{17}$

Watson's (2001: 130) overview of the election suggests that such variation in England is 'perhaps inevitable given that 319 (Acting) Returning Officers are making individual decisions with no overall coordination' and goes on to call for a power of direction to be granted to either the Electoral Commission or other electoral management board in much the same way as in Scotland. While this may help increase performance, as might public exposure of errors evident in the polling night queues, it is important to recognise that coordination is no necessary guarantee of performance even if it does seem to help. Indeed, Scottish electoral administration did not perform uniformly and varied between scores of 14 and 21 in 2010, while Wales also had some experience of co-ordinating electoral administration in 2007 and 2009 yet was only fifth out of seven council types in 2010 . Variation in standards is therefore to be expected, both within and between different council types and regions. Moreover, even if the direction of travel is towards meeting standards, the experience of authorities falling backwards and failing to meet standards is also to be expected. Indeed, a number of authorities' self-assessments were downgraded in 2010 despite them having met the relevant standard in 2009 (Electoral Commission, 2010b: 24-25). Managing variation and backsliding are equally things that the Electoral Commission will have to address in due course, and this will ultimately be a continuous process. As Watson (2011: 142) puts it:

We cannot rely upon a system that trusts that the machinery of electoral administration will always work well and deliver elections to a consistently high standard. Trust may 
have been a sufficient anchor for the system in the past, but while trust is good, caution and deterrent controls are better.

\section{Conclusion}

This article has provided an important overview of electoral administration in Britain in the 2010 general election. This election was marred by television pictures of voters not being able to vote, which called the integrity of the electoral process in some constituencies into doubt. This happened despite supposedly high standards of electoral administration existing across Britain, as highlighted by the Electoral Commission's review of performance standards in the 2009 European contest. As underlined by a number of other difficulties in recent years, electoral administration in Britain is therefore ripe for research and, as some scholars observe (Alvarez et al., 2008; Gerken, 2009), such research may have the potential to help improve electoral processes.

This article has made a number of important contributions to debates on electoral integrity in Britain and elsewhere. Firstly, most British electoral administrators in local councils perform their incredibly complex electoral duties to a high standard. However, not all do so to the same level and the index of electoral integrity provides a more nuanced measure of this than the Electoral Commission's 'not meeting the standard' category. Secondly, the index of electoral integrity outlined here provides an additional tool for electoral administrators and academics to judge election quality more generally. It is therefore a practical application of calls by comparative scholars, primarily working in the field of democratic transitions, for academics to assess election quality comprehensively. While not as wide-ranging as, for instance, Elklit and Reynolds' (2005) schema, the index nevertheless takes account of actions at all stages of the electoral process from training and 
planning, to the integrity of casting a vote and the information electors and candidates have available. The index therefore provides an additional performance management assessment for administrators, while also providing analysts with an additional variable to examine election quality in Britain. Thirdly, its use has been demonstrated by applying it specifically to the electoral structure of the area administered, and the different local authority types and regions in mainland Britain in the 2010 general election. Statistically significant and systematic differences have been found between a number of these indicators and the integrity index, which take the exploratory findings reported here beyond those reported by the Electoral Commission (2009b; 2010b). They also provide ideas and variables which may be tested in other advanced democracies, not least in the USA where such research is most advanced. Clearly in Britain some councils and regions have some way to go to reach the standards of the best in electoral administration. More research is required in order to understand the factors which impact upon this. This might include extending such analyses to different rounds of elections as well as developing analyses over time, in addition to developing multivariate models to develop explanation further. As public budgets come under stress, electoral services, used irregularly but for a democratically important and high profile purpose, will also come under pressure. ${ }^{18}$ Maintaining standards even for the best will be difficult, while poorer performing authorities are likely to face an even greater challenge. These standards will need to be continually monitored, developed and policed by the Electoral Commission and by ROs themselves if there is to be no repeat of any of the recent problems in British electoral administration. ${ }^{19}$ 


\section{References:}

ACE Electoral Knowledge Network (n.d.) 'Overview of Electoral Integrity', http://aceproject.org/ace-en/topics/ei/ei10 [16th March 2012].

Alvarez, R. M. and Hall, T. E. (2006) 'Controlling Democracy: The Principal-Agent Problems in Election Administration', Policy Studies Journal, 34, (4), pp491-510.

Alvarez, R. M., Hall, T. E. and Hyde, S. D. (eds.) (2008) Election Fraud: Detecting and Deterring Electoral Manipulation, Washington DC: Brookings Institute.

Andrews, R., Boyne, G. A., Law, J. and Walker, R. M. (2005) 'External Constraints on Local Service Standards: The Case of Comprehensive Performance Assessment in English Local Government', Public Administration, 83, (3), pp639-656.

Atkeson, L. R. and Saunders, K. L. (2007) 'The Effect of Election Administration on Voter Confidence: A Local Matter?, PS: Political Science and Politics, 40, (4), pp655-660.

Birch, S. (2011) Electoral Malpractice, Oxford: Oxford University Press.

Clark, A. (2014) 'Investing in Electoral Management' in P. Norris, R. Frank \& F. Martinez I Coma (eds.) Advancing Electoral Integrity, New York: Oxford University Press.

Denver, D., Johns, R. and Carman, C. (2009) 'Rejected Ballot Papers in the 2007 Scottish Parliament Election: The Voters' Perspective', British Politics, 4, (1), pp3-21.

Editorial (2012) 'Our Democratic Process Needs Better Safeguards', The Independent, $3^{\text {rd }}$ May, p.18.

Electoral Commission (2007a) Scottish Elections 2007, Edinburgh: Electoral Commission.

Electoral Commission (2007b) Scottish Elections 2007: The Independent Review of the Scottish Parliamentary and Local Government Elections 3 May 2007, Edinburgh: Electoral Commission. 
Electoral Commission (2009a) Performance Standards for Returning Officers in Great Britain, London: Electoral Commission.

Electoral Commission (2009b) Report on Performance Standards for Returning Officers in Great Britain: European Parliamentary Elections 2009, London: Electoral Commission.

Electoral Commission (2010a) 2010 UK Parliamentary General Election: Interim Report: Review of Problems at Polling Stations at Close of Poll on 6 May 2010, London: Electoral Commission

Electoral Commission (2010b) Report on Performance Standards for (Acting) Returning Officers in Great Britain: UK General Election 2010, London: Electoral Commission.

Electoral Commission (2011a) Report on the Northern Ireland Assembly Election on 5 May 2011, Belfast: Electoral Commission.

Electoral Commission (2011b) Performance Standards for Returning Officers in Great Britain, London: Electoral Commission.

Electoral Commission (2012) The Cost of Electoral Administration in Great Britain, London: Electoral Commission.

Elklit, J. and Reynolds, A. (2001) 'Analysing the Impact of Election Administration on Democratic Politics', Representation, 38, (1), pp3-10.

Elklit, J. and Reynolds, A. (2005) 'A Framework for the Systematic Study of Election Quality', Democratization, 12, (2), pp147-162.

Elklit, J. and Svensson, P. (1997) 'What Makes Elections Free and Fair?', Journal of Democracy, 8, (3), pp32-46.

Game, C. (2006) 'Comprehensive Performance Assessment in English Local Government', International Journal of Productivity and Performance Management, 55, (6), pp466479. 
Gerken, H. K. (2009) The Democracy Index: Why Our Election System is Failing and How to Fix It, Princeton: Princeton University Press.

Hale, K. and Slaton, C. D. (2008) 'Building Capacity in Election Adminstration: Local Responses to Complexity and Interdependence', Public Administration Review, 68, (5), pp839-849.

Hall, T., Monson, J. Q., and Patterson, K. D. (2007) 'Poll Workers and the Vitality of Democracy: An Early Assessment', PS: Political Science and Politics, 40, (4), pp647654.

Heckman, J., Heinrich, C. and Smith, J. (1997) 'Assessing the Performance of Performance Standards in Public Bureaucracies', American Economic Review, 87, (2), pp389-395.

Heinrich, C. J. (2002) 'Outcomes-Based Performance Management in the Public Sector: Implications for Government Effectiveness', Public Administration Review, 62, (6), pp712-725.

Highton, B. (2006) 'Long Lines, Voting Machine Availability, and Turnout: The Case of Franklin County, Ohio in the 2004 Presidential Election', PS: Political Science and Politics, 39, (1), pp65-68.

James, T. S. (2010) 'Electoral Modernisation or Elite Statecraft: Electoral Administration in the United Kingdom 1997-2007', British Politics, 5, (2), pp179-201.

James, T.S. (2013) 'Fixing Failures of U.K. Electoral Management', Electoral Studies, 32, (4), pp597-608.

Maley, M. (2001) 'The Australian Electoral Commission: Balancing Independence and Accountability', Representation, 38, (1), pp25-30.

Mawrey, R. (2005) Fraud at the Elections, Nottingham: Spokesman Books.

Minnite, L. C. (2010) The Myth of Voter Fraud, Cornell University Press. 
Montjoy, R. S. (2008) 'The Public Administration of Elections', Public Administration Review, 68, (5), pp788-799.

Mozaffar, S. and Schedler, A. (2002) 'The Comparative Study of Electoral Governance: An Introduction', International Political Science Review, 23, (1), pp5-27.

Murphy, P., Greenhalgh, K. and Jones, M. (2011) 'Comprehensive Performance Assessment and Public Services Improvement in England? A Case Study of the Benefits Administration Service in Local Government', Local Government Studies, 37, (6), pp579-599.

Norris, P. (2013a) 'The New Research Agenda Studying Electoral Integrity', Electoral Studies, 32, (4), pp563-575.

Norris, P. (2013b) 'Does the world agree about standards of electoral integrity? Evidence for the diffusion of global norms', Electoral Studies, 32, (4), pp576-588.

OSCE Office for Democratic Institutions and Human Rights (2010a) Election Observation Handbook, $6^{\text {th }}$ Edition, Warsaw: OSCE/ODIHR.

OSCE/ODIHR (2010b) United Kingdom of Great Britain and Northern Ireland General Election 6 May 2010: Election Assessment Mission Report, Warsaw, OSCE/ODHIR.

Pastor, R. A. (1999) 'The Role of Electoral Administration in Democratic Transitions: Implications for Policy and Research', Democratization, 6, (4), pp1-27.

Pennings, P., Keman, H. and Kleinnijenhuis, J. (1999) Doing Research in Political Science, London: Sage.

Schaffer, F. C. (2008) The Hidden Costs of Clean Election Reform, Ithaca, NY: Cornell University Press.

Stewart. J. (2006) 'A Banana Republic? The Investigation into Electoral Fraud by the Birmingham Election Court', Parliamentary Affairs, 59, (4), pp654-667. 
Taylor, J. and Rawlinson, K. (2012) 'They Knock on the Door and Ask us to Give Them Our Ballot Papers', The Independent, $3^{\text {rd }}$ May.

Vickery, C. and Shein, E. (2012) Assessing Electoral Fraud in New Democracies: Refining the Vocabulary, Washington DC: IFES.

Watson, J. (2011) 'Public Confidence in Elections', in Wring, D., Mortimore, R. and Atkinson, S. (eds.) Political Communication in Britain: The Leader Debates, The Campaign and the Media in the 2010 General Election, Basingstoke: Palgrave, pp126143.

Wilks-Heeg, S. (2009) 'Treating Voters as an Afterthought? The Legacies of a Decade of Electoral Modernisation in the United Kingdom', Political Quarterly, 80, (1), pp101110.

Wise, C. R. (2001) 'Election Administration in Crisis: An Early Look at Lessons from Bush Versus Gore', Public Administration Review, 61, (2), pp131-139. 
Table 1: Performance Standards for Returning Officers in the 2010 general election

\begin{tabular}{|l|l|}
\hline Subject & Performance standard \\
\hline Planning \& organisation & 1: Skills \& knowledge of returning officer \\
\cline { 2 - 2 } & 2: Planning processes in place for an election \\
\cline { 2 - 2 } & 3: Training \\
\hline Integrity & 4: Maintaining the integrity of an election \\
\hline Participation & 5: Planning and delivering public awareness activity \\
\cline { 2 - 2 } & 6: Accessibility of information to electors \\
\cline { 2 - 2 } & 7: Communication of information to candidates \& agents \\
\hline
\end{tabular}

Sources: Electoral Commission, 2009a; 2010b: 2.

Table 2: Performance standards in the 2009 European and 2010 general elections (\%)

\begin{tabular}{|c|c|c|c|c|c|}
\hline & & $\begin{array}{l}\text { Not meeting } \\
\text { standard }\end{array}$ & $\begin{array}{l}\text { Meeting } \\
\text { standard }\end{array}$ & $\begin{array}{l}\text { Above } \\
\text { standard }\end{array}$ & $\mathrm{N}$ \\
\hline \multirow[t]{7}{*}{2009} & Skills \& knowledge & 3.2 & 77.8 & 19.0 & 378 \\
\hline & Planning processes & 5.0 & 65.9 & 29.1 & 378 \\
\hline & Training & 1.9 & 78.8 & 19.3 & 378 \\
\hline & Integrity & 18.8 & 75.1 & 6.1 & 378 \\
\hline & $\begin{array}{l}\text { Public awareness } \\
\text { activity }\end{array}$ & 11.9 & 70.9 & 17.2 & 378 \\
\hline & $\begin{array}{l}\text { Accessibility of } \\
\text { information to electors }\end{array}$ & 18.3 & 74.1 & 7.7 & 378 \\
\hline & $\begin{array}{l}\text { Communication to } \\
\text { candidates \& agents }\end{array}$ & 1.6 & 70.4 & 28.0 & 378 \\
\hline \multirow[t]{7}{*}{2010} & Skills \& knowledge & 1.9 & 73.9 & 24.2 & 372 \\
\hline & Planning processes & 2.2 & 53.8 & 44.1 & 372 \\
\hline & Training & 1.6 & 68.0 & 30.4 & 372 \\
\hline & Integrity & 5.6 & 83.6 & 10.8 & 372 \\
\hline & $\begin{array}{l}\text { Public awareness } \\
\text { activity }\end{array}$ & 3.2 & 67.5 & 29.3 & 372 \\
\hline & $\begin{array}{l}\text { Accessibility of } \\
\text { information to electors }\end{array}$ & 8.1 & 79.0 & 12.9 & 372 \\
\hline & $\begin{array}{l}\text { Communication to } \\
\text { candidates \& agents }\end{array}$ & 0.3 & 54.4 & 45.3 & 371 \\
\hline
\end{tabular}

Source: http://www.electoralcommission.org.uk/find-information-by-subject/performancestandards/performance-in-running-elections-and-referendums 
Figure 1: Integrity index, 2010 general election

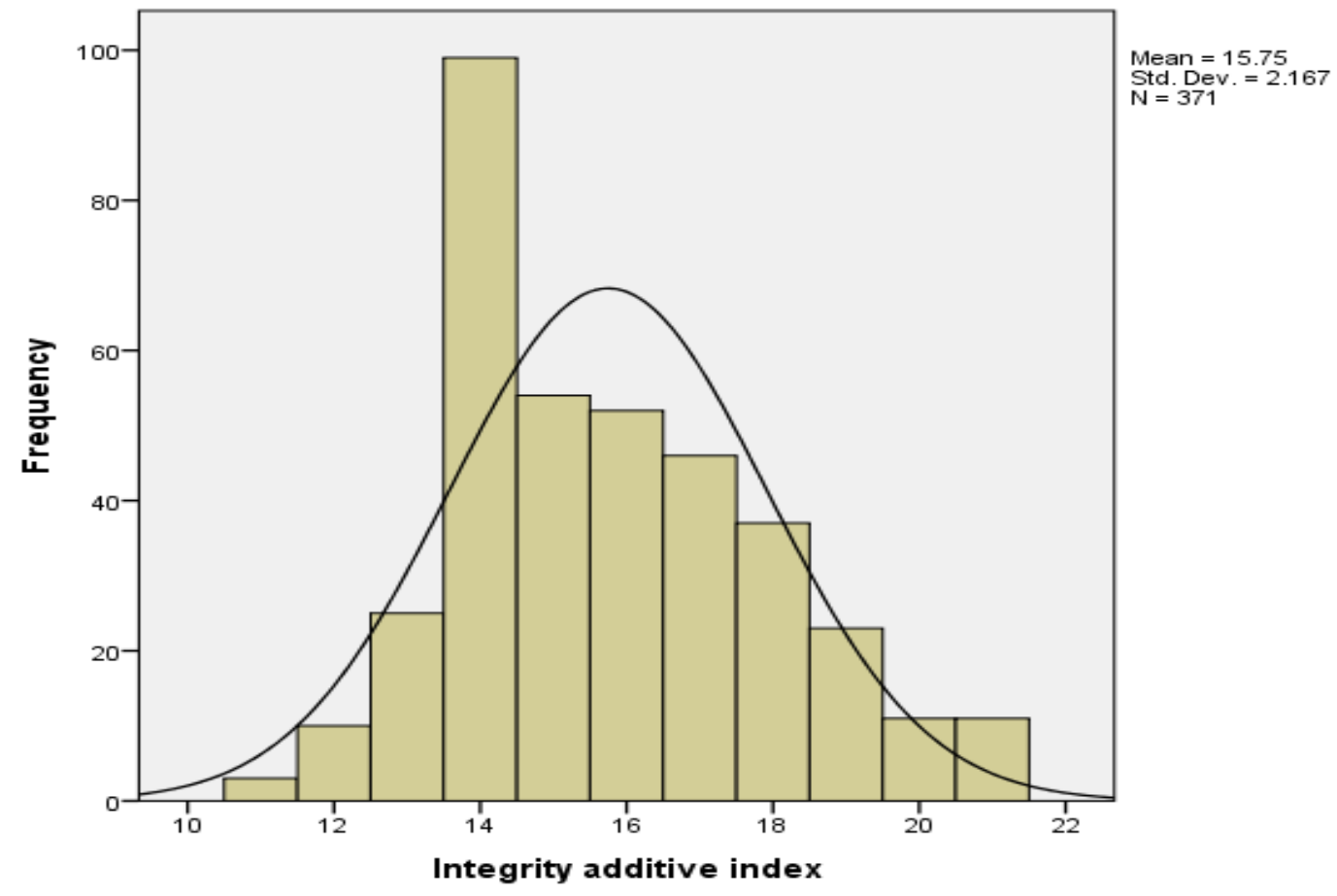

Table 3: Highest and lowest scoring local authorities, 2010 general election

\begin{tabular}{|l|c|l|c|}
\hline Highest & & Lowest & \\
\hline Authority & Index score & Authority & Index score \\
\hline Cornwall & 21 & Adur & 12 \\
\hline Ealing & 21 & Barking and Dagenham & 12 \\
\hline Lewisham & 21 & Bristol & 12 \\
\hline Pembrokeshire & 21 & Carlisle & 12 \\
\hline Perth and Kinross & 21 & Christchurch & 12 \\
\hline Reading & 21 & Hambleton & 12 \\
\hline Rotherham & 21 & Hertsmere & 12 \\
\hline Selby & 21 & Newcastle upon Tyne & 12 \\
\hline Swindon & 21 & Weymouth and Portland & 12 \\
\hline Tameside & 21 & Worthing & 12 \\
\hline Westminster & 21 & Lambeth & 11 \\
\hline & & N.E. Lincolnshire & 11 \\
\hline & & Rugby & 11 \\
\hline
\end{tabular}

Note: Authorities are presented in alphabetical order in each column and performance score. 
Table 4: Integrity index by council type, 2010 general election

\begin{tabular}{|l|c|c|c|}
\hline Authority type & Mean index score & Std. Deviation & N \\
\hline Scottish unitary & 16.68 & 2.197 & 31 \\
\hline London borough & 16.44 & 2.526 & 32 \\
\hline Unitary county & 16.11 & 2.472 & 9 \\
\hline Metropolitan district & 16.08 & 2.322 & 36 \\
\hline Welsh unitary & 15.91 & 2.158 & 22 \\
\hline Unitary district & 15.75 & 2.304 & 44 \\
\hline Two-tier district & 15.39 & 1.968 & 197 \\
\hline Total & 15.75 & 2.167 & 371 \\
\hline
\end{tabular}

Table 5: Integrity index by English region, 2010 general election

\begin{tabular}{|l|c|c|c|}
\hline Region & Mean index score & Std. Deviation & N \\
\hline $\begin{array}{l}\text { Yorkshire and } \\
\text { Humber }\end{array}$ & 16.00 & 3.195 & 20 \\
\hline South East & 15.87 & 2.187 & 67 \\
\hline South West & 15.79 & 2.302 & 33 \\
\hline East Midlands & 15.76 & 1.895 & 38 \\
\hline West Midlands & 15.67 & 1.900 & 30 \\
\hline North East & 15.42 & 2.193 & 39 \\
\hline North West & 15.28 & 1.746 & 47 \\
\hline Eastern & 14.79 & 1.573 & 39 \\
\hline
\end{tabular}


$\overline{{ }^{1} \text { Earlier versions of this article were presented at PSA Annual Conference in Belfast, at the pre-IPSA Electoral }}$ Integrity Workshop at Complutense University of Madrid, both in 2012, and at the EPOP Conference, University of Lancaster in 2013. I am grateful to participants, and also Jocelyn Mawdsley and Derek Bell, for helpful comments. The usual disclaimer applies.

${ }^{2}$ See also the 2008 symposium on US Electoral Administration in Public Administration Review, 68 (5).

${ }^{3}$ As allegations of electoral fraud over postal voting and registration in the 2012 local elections demonstrate, this difficulty persists (Taylor and Rawlinson, 2012).

${ }^{4}$ Remarkably there were no election petitions challenging any of the results (Electoral Commission, 2007a: 21).

${ }^{5}$ For a full list of the constituencies, local authorities and polling stations affected, see Electoral Commission (2010a).

${ }^{6}$ For the full list of criteria for each performance standard, see Electoral Commission (2009a).

${ }^{7}$ Most social science surveys are also self-completed, with few issues being raised about their acceptability for analysis. If ROs were systematically overstating their performance, it might also be expected that there would be little variation in responses. As analysis shows, such variation is clearly evident.

${ }^{8}$ The complete spreadsheets with RO data are available from: http://www.electoralcommission.org.uk/findinformation-by-subject/performance-standards/performance-in-running-elections-and-referendums [15/11/13].

${ }^{9}$ Consideration was given to weighting these standards. However deficiencies in any aspect can cause complications and difficulties with the electoral process. Many difficulties can be attributed to poor planning, while accessibility of information to electors would seem to be crucial for voters to be well informed about the process. In the absence of any accepted weighting standard, the approach adopted here has weighted each aspect equally.

${ }^{10}$ In other words, this includes ROs from councils in England, Scotland and Wales. It excludes Northern Ireland, which is exempt from these performance standards and has different arrangements with the provincewide Electoral Office of Northern Ireland responsible for administering most elections there. There is no obvious systematic pattern to the missing data, evident in councils across Britain. Missing councils are: Rutland, City of London, Shetland Islands, Purbeck, West Somerset, Richmondshire and East Dorset.

${ }^{11}$ Pennings et al. (1999: 96-97) note that a Cronbach's Alpha score of .7 or over means that the component indicators of such an index are suitable and that creating an index from such variables 'adds to the discriminating power of the theoretical concept'. 
${ }^{12}$ Subsequent to the first presentation of this index at the pre-IPSA Electoral Integrity workshop in July 2012, witnessed by a Commission representative, the idea of such an index was used briefly in a December 2012 report on election spending (Electoral Commission, 2012: 16-18), but little systematic analysis was done on it.

${ }^{13}$ Electorate density is calculated from the electorate and hectare data in the Electoral Commission's electoral costs data, available at: http://www.electoralcommission.org.uk/find-information-by-subject/performancestandards/financial-information [17/1/14].

${ }^{14}$ This is a simple yes-no indicator of whether that council was also administering local elections in 2010. Data on concurrent elections was taken from the Guardian's summary of the 2010 local elections, available at: http://www.theguardian.com/society/table/2010/may/07/local-elections [22/11/13].

${ }^{15}$ While a council's boundaries may overlap several constituencies, it is not necessarily the case that that council's RO administers each of those constituencies as they may be run by neighbouring councils. It is seldom clear from council websites which constituencies they are responsible for administering where this is the case, since they often report the results for all the constituencies residents may have parliamentary representation in. In the absence of precise numbers, this is a simple yes-no indicator of whether they are likely to be responsible for multiple constituencies or not. I am grateful to Phil Thompson and Gemma Rosenblatt of the Electoral Commission for providing data on this for English councils. Data for Scottish and Welsh councils was estimated from their websites.

${ }^{16}$ For Scottish unitaries, the standard deviation means that the main range of performance is between 14.483 and 18.877; for London boroughs, between 13.914 and 18.966 and for two-tier districts 13.422 and 17.358.

${ }^{17}$ This regional analysis of variance includes Scotland, Wales and London regions.

${ }^{18}$ On the costs of electoral administration, see Clark (2014).

${ }^{19}$ See the Commission's new set of performance standards developed after consultation and published in December 2011. These have broadened the standards to account for administering the poll, absent voting, verifying and counting, and also include post-election procedures (Electoral Commission, 2011b). While broadening the scope of the standards, they do however undermine the ability to compare performance over time. 